\title{
Bullying in the nursing work environment: integrative review
}

\author{
Bullying no ambiente de trabalho da Enfermagem: revisão integrativa \\ Bullying en el medio ambiente de trabajo de la enfermería: revisión integrativa
}

\author{
Roberta Nazario Aokia \\ Edinêis de Brito Guirardello ${ }^{a}$
}

\section{How to cite this article:}

Aoki RN, Guirardello EB. Bullying

in the nursing work environment: integrative review. Rev Gaúcha Enferm.

2019:40:e20190176. doi: https://doi. org/10.1590/1983-1447.2019.20190176 aniversidade Estadual de Campinas (UNICAMP), Faculdade de Enfermagem, Programa de PósGraduação em Enfermagem. Campinas, São Paulo, Brasil.

\begin{abstract}
Objective: To evaluate the studies that approach bullying in the nursing practice environment.

Method: Integrative review, conducted between April and December 2018, by combining the descriptors "bullying/bullying" AND "nursing/nursing/nurse" AND "workplace/workplace". We identified 224 studies of which 38 met the inclusion criteria.

Results: The studies on nursing bullying presented three main approaches related to the prevalence in nursing practice, the repercussions for health and professional development, and the construction of theoretical models for bullying and nursing work environment variables.
\end{abstract}

Conclusion: Bullying is a negative behavior present in the nursing practice environment and has a direct impact on professional performance, impairing general health and professional performance. Despite being a behavior with recognized negative potential in the work environment, few studies propose effective actions to prevent or control this phenomenon in health institutions.

Keywords: Bullying. Nursing. Workplace. Review literature as topic.

\section{RESUMO}

Objetivo: Avaliar os estudos que abordam o bullying no ambiente de prática da enfermagem.

Método: Revisão integrativa, realizada no período de abril a dezembro de 2018, por meio da combinação entre os descritores "bullying / bullying" AND"enfermagem/nursing/nurse" AND"local de trabalho/workplace". Foram identificados 224 estudos dos quais 38 atenderam aos critérios de inclusão.

Resultados: Os estudos sobre bullying na enfermagem apresentaram três enfoques principais relacionados à prevalência na prática da enfermagem, às repercussões para a saúde e desenvolvimento profissional e construção de modelos teóricos para o bullying e variáveis do ambiente de trabalho da enfermagem.

Conclusão: 0 bullying é um comportamento negativo presente no ambiente da prática da enfermagem e apresenta impacto direto na atuação profissional, ao prejudicar a saúde geral e o desempenho profissional. Apesar de ser um comportamento com reconhecido potencial negativo ao ambiente de trabalho, poucos estudos propõem ações efetivas para prevenção ou controle deste fenômeno nas instituições de saúde.

Palavras-chave: Bullying. Enfermagem. Local de trabalho. Literatura de revisão como assunto.

\section{RESUMEN}

Objetivo: Evaluar los estudios que abordan el bullying en el entorno de la práctica de enfermería

Método: Revisión integradora, realizada entre abril y diciembre de 2018, mediante la combinación de los descriptores "bullying / bullying" AND "enfermería / enfermería / enfermera" AND "lugar de trabajo / lugar de trabajo". Se identificaron 224 estudios, de los cuales 38 cumplieron con los criterios de inclusión.

Resultados: Los estudios sobre el bullying de enfermería presentaron tres enfoques principales relacionados con la prevalencia en la práctica de enfermería, las repercusiones para la salud y el desarrollo profesional, y la construcción de modelos teóricos para las variables de entorno de bullying y trabajo de enfermería.

Conclusión: El acoso es un comportamiento negativo presente en el entorno de la práctica de enfermería y tiene un impacto directo en el desempeño profesional, lo que afecta la salud general y el desempeño profesional. A pesar de ser un comportamiento con potencial negativo reconocido en el entorno laboral, pocos estudios proponen acciones efectivas para prevenir o controlar este fenómeno en las instituciones de salud.

Palabras clave: Acoso escolar. Enfermería. Lugar de trabajo. Literatura de revisión como asunto. 


\section{口INTRODUCTION}

In the last decades of the $20^{\text {th }}$ century, the global economic scenario has undergone profound changes that, in turn, modified the structure of work processes, made the labor environment more competitive and hostile(1) and exposed employees to new work-related risks ${ }^{(2)}$.

It is believed that occupational risks have always existed; since the $1980 \mathrm{~s}^{(3)}$, however, abuse toward workers has been compared to uncivil acts among schoolchildren and thus received the denomination mobbing ${ }^{(4)}$, consequently leading to more critical analyses on the part of the researchers $^{(3-5)}$. It is noteworthy that expressions such as mobbing, harassment, bullying and horizontal violence are used as synonyms to describe personal, moral and psychological violence in the workplace and the preferred term depends on the region of the studies ${ }^{(6-7)}$.

Bullying is characterized as systematic and persistent behavior occurring for more than six months in the form of repeated negative acts such as insulting observations, exposure of the victim, verbal abuse, offensive provocation, isolation and social exclusion or the constant degradation of working conditions and worker effort ${ }^{(8)}$.

Negative attitudes caused by bullying can trigger high levels of stress, mental and psychological disorders, including anxiety and depression among workers ${ }^{(9)}$. Other physical manifestations include gastrointestinal disorders, hypertension, headache and eating and sleep disorders, which eventually affect the sufferer's overall health ${ }^{(10)}$. In addition, it may result in dissatisfaction with work and social isolation ${ }^{(11-13)}$. For the institution, bullying can cause an increase in absenteeism, a reduction in productivity and efficiency and job abandonment ${ }^{(13-14)}$.

Studies in health care show that bullying accounts for up to a quarter of all work-related cases of violence ${ }^{(3,15)}$ and that nursing professionals are more exposed to bullying by their peers, by other professionals and even by patients ${ }^{(10,16-17)}$.

Nursing is a predominantly female professional category and, as such, still subjected to gender-related workplace inequalities, which have already be related to higher rates of workplace bullying'. Moreover, nursing is the largest and one of the most stressful professional categories in the field of health since nurses must cope with the demands of patients, other professionals and their own coworkers ${ }^{(2)}$. Nursing professionals must endure situations of anguish and pain, work overload and extensive work shifts on a daily basis ${ }^{(15)}$, all of which expose them to workplace bullying.

Considering the negative repercussions of bullying on the performance and physical and emotional health of workers, especially nurses, it is important to understand its dimensions in the workplace in order to implement preventive and control actions and favor a positive safety culture in health care institutions. Consequently, the aim of this paper was to assess studies on bullying in the nursing work environment.

\section{METHOD}

This is an integrative review conducted according to the stages recommended by Whittemore and Knafl(18), namely a) problem identification and creation of research question; b) establishment of inclusion and exclusion criteria and literature search; c) definition of information to be collected in the studies obtained in the search; d) categorization of selected studies and analysis of this information; e) interpretation of results and f) review presentation.

In the first stage, the following question was formulated: What is the focus of studies on bullying in the nursing work environment? After defining the guiding question, the study selection stage was initiated.

Prior to selection, the following inclusion criteria were adopted: publications with all the descriptors cited in the title of the study and full-text publications in Portuguese, English or Spanish published between January 2010 and December 2018. Studies of integrative or systematic reviews, editorials, letters, theses and dissertations and duplicate papers were excluded.

In the third stage, the online search for studies was carried out. We consulted the primary source databases Web of Science (WOS), MEDLINE/PubMed, Embase, Cumulative Index to Nursing and Allied Health Literature (CINAHL) and Latin American and Caribbean Literature on Health Sciences (LILACS). The search strategy comprised the operators "bullying/bullying" AND "enfermagem/nursing/nurses"AND "local de trabalho/workplace". The descriptors used are standardized in the Health Sciences Descriptors (DeCS) and the Medical Subject Headings (MeSH).

The database searches resulted in 224 studies, which went through further selection stages. The flow of study selection is shown in Figure 1, based on PRISMA recommendations for preparing a flow diagram of the stages of this integrative review ${ }^{(19)}$

In the following stage, the studies listed in an Excel spreadsheet were characterized in descending order according to year and country of publication, authors, title, study objectives, methodology and main results. In the fifth stage, the main findings were interpreted and synthesized and, finally, the review was presented. 


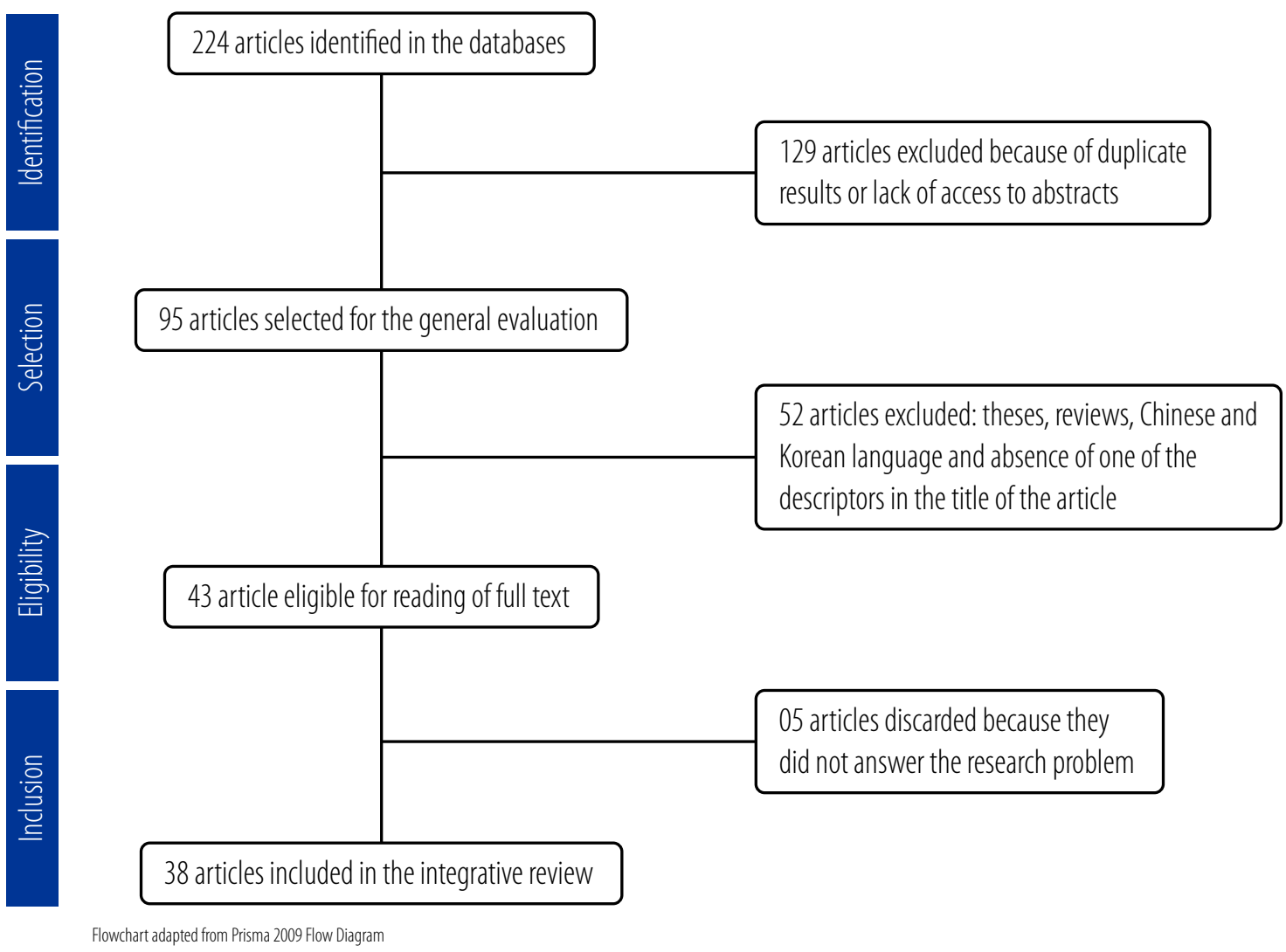

Figure 1 - Flowchart prepared and adapted from the PRISMA recommendations for mapping the articles that are identified, selected and included.

Source: Research data, 2018.

\section{RESULTS}

Based on the descriptors of DeCS and MeSH, we identified 224 articles in the databases, three of which were in LILACS, 18 in CINAHL, 29 in MEDLINE/PubMed, 118 in Embase and 50 in the Web of Science. Of these studies, 186 articles were excluded because they were duplicates, they did not refer to the subject matter or they did not meet the criteria, resulting in 38 articles. The main characteristics of the studies - such as first author, year of publication, country, objectives and main results - are presented in Chart 1.

To analyze the results, the findings were categorized according to the key focal points attributed to bullying in nursing: 1) perception of bullying 2) impact of bullying on health care and professional performance and 3) construction of theoretical models on bullying in nursing.

\section{First author, year and country \\ Objectives \\ Main results}

Logan ${ }^{(20)} \quad$ Exploring nurses' perceptions

USA harassment.
$2018 \quad$ of teamwork and workplace

Two-thirds of nurses reported the presence of important variables such as leadership, trust and communication in their teams. One-third of the nurses reported being bullied and half observed others being intimidated.

A relationship-oriented organizational culture had a direct Yun ${ }^{(21)} \quad$ Build and test a model outlining 2018 factors related to moral Korea harassment effect on harassment, and harassment had a direct effect on the experience mediated by positive psychological capital. Harassment also had an indirect effect on the intention to leave the workplace. 


\section{First author, year and country}

Objectives

Main results

\begin{tabular}{|c|c|c|}
\hline $\begin{array}{l}\text { Savaşan } \\
2018 \\
\text { Turkey }\end{array}$ & $\begin{array}{l}\text { Examining the relationship } \\
\text { between personality } \\
\text { characteristics and bullying }\end{array}$ & $\begin{array}{l}\text { Significant negative, albeit weak correlations were found } \\
\text { between Hacettepe Personality Inventory scores (general, } \\
\text { personal and social adjustment points) and bullying scores. }\end{array}$ \\
\hline $\begin{array}{l}\text { Olender } \\
2017 \\
\text { USA }\end{array}$ & $\begin{array}{l}\text { Examining the relationship } \\
\text { between team members' } \\
\text { perceptions of moral harassment }\end{array}$ & $\begin{array}{l}\text { A significant inverse relationship was found between nursing } \\
\text { managers and exposure to bullying in the workplace. Sex, work } \\
\text { environment and high workload influenced these findings. }\end{array}$ \\
\hline $\begin{array}{l}\text { Olsen(24) } \\
2017 \\
\text { Norway }\end{array}$ & $\begin{array}{l}\text { Further understand workplace } \\
\text { harassment and relate it to the } \\
\text { work climate. }\end{array}$ & $\begin{array}{l}\text { Most of the characteristics of the work climate influenced mora } \\
\text { harassment in the workplace. Bullying played a mediating role } \\
\text { in most dimensions of the work climate, such as performance, } \\
\text { satisfaction and the ability to work. }\end{array}$ \\
\hline $\begin{array}{l}\text { Kang }^{(25)} \\
2017 \\
\text { Korea }\end{array}$ & $\begin{array}{l}\text { Investigate the effects of a } \\
\text { cognitive testing program on } \\
\text { moral harassment }\end{array}$ & $\begin{array}{l}\text { After the intervention, significant differences were found } \\
\text { in interpersonal relationships and turnover intention for } \\
\text { the experimental groups and the waiting list. However, no } \\
\text { significant difference was found for moral harassment betweer } \\
\text { the two groups. }\end{array}$ \\
\hline $\begin{array}{l}\text { An } \\
2017 \\
\text { Korea }\end{array}$ & $\begin{array}{l}\text { Identify the relationship } \\
\text { between organizational culture } \\
\text { and the bullying experience }\end{array}$ & $\begin{array}{l}\text { The prevalence was } 15.8 \% \text {. Multivariate analysis revealed that } \\
\text { the chances of being bullied were } 2.58 \text { times higher among } \\
\text { nurses in a hierarchy-oriented culture than among nurses in a } \\
\text { relationship-oriented culture. }\end{array}$ \\
\hline
\end{tabular}

Blackwood $^{(27)}$

2017

New Zealand
Investigate the role of workplace factors in bullying behavior
A number of work environment factors affect the efficacy of bullying intervention in the nursing workplace.

$\begin{array}{ll}\text { Karatza }^{(14)} & \text { Identify the impact of bullying } \\ 2017 & \text { on nursing professionals } \\ \text { Greece } & \end{array}$

Nwaneri ${ }^{(28)}$

2017

Nigeria

Assess the occurrence and effects of bullying among nurses.
One-third of the nurses reported bullying in the last six months. The impact of bullying on nurses varied depending on the family support or the friendly environment provided to cope with moral harassment in the workplace.

The prevalence among nurses who worked in tertiary hospitals was reported as high. The effects of bullying on nurses include anger, the desire to travel abroad because of the feeling that the prevalence is lower, frustraton and tense social relations among coworkers.

$\begin{array}{ll}M a^{(29)} & \text { Explore the relationships } \\ 2017 & \text { between negative perceptions } \\ \text { Taiwan } & \text { and negative acts on bullying }\end{array}$

$80 \%$ of nurses experience bullying at some point in their professional lives. The consequences of bullying are severe psychological trauma; low self-esteem; depression and anxiety; post-traumatic stress; physical disease; financial loss and eventual inability to work.

$\begin{array}{ll}\text { Bardakci(30) } & \text { To determine the effects of } \\ 2016 & \text { bullying on the psychological } \\ \text { Turkey } & \text { distress of nurses. }\end{array}$

Nurses with master's degrees were more exposed to bullying. The nurses exposed to bullying had higher levels of psychological distress and preferred to keep quiet about it. The nursing managers were the main bullies. 


\section{First author, year and country \\ Objectives \\ Main results}

$\begin{array}{ll}\text { Tee }^{(31)} & \text { Explore and describe the } \\ 2016 & \text { incidence and experiences of } \\ \text { England } & \text { bullying in nursing. }\end{array}$

$\begin{array}{ll}\text { Fang }^{(32)} & \text { Investigate bullying } \\ 2016 & \text { among nurses. }\end{array}$

\begin{tabular}{ll}
\hline $\begin{array}{l}\text { Giorgi( }_{233} \\
\text { Italy }\end{array}$ & $\begin{array}{l}\text { Develop a bullying model } \\
\text { focused on the interaction } \\
\text { between bullying and burnout }\end{array}$ \\
\hline $\begin{array}{l}\text { Karatza }{ }^{(11)} \\
2016\end{array}$ & $\begin{array}{l}\text { Investigate the relationship } \\
\text { Greece }\end{array}$ \\
\hline & $\begin{array}{l}\text { between bullying and the } \\
\text { Oh(34) }\end{array}$ \\
2016 & Identify individual and \\
Korea & institutional characteristics for \\
& moral harassment
\end{tabular}

\begin{tabular}{|c|c|}
\hline $\begin{array}{l}\text { Giorgi(33) } \\
2016 \\
\text { Italy }\end{array}$ & $\begin{array}{l}\text { Develop a bullying model } \\
\text { focused on the interaction } \\
\text { between bullying and burnout }\end{array}$ \\
\hline $\begin{array}{l}\text { Karatza }^{(11)} \\
2016 \\
\text { Greece }\end{array}$ & $\begin{array}{l}\text { Investigate the relationship } \\
\text { between bullying and the } \\
\text { general health status of nursing }\end{array}$ \\
\hline $\begin{array}{l}\mathrm{Oh}^{(34)} \\
2016 \\
\text { Korea }\end{array}$ & $\begin{array}{l}\text { Identify individual and } \\
\text { institutional characteristics for } \\
\text { moral harassment }\end{array}$ \\
\hline
\end{tabular}

\begin{tabular}{|c|c|}
\hline $\begin{array}{l}\text { Giorgi(33) } \\
2016 \\
\text { Italy }\end{array}$ & $\begin{array}{l}\text { Develop a bullying model } \\
\text { focused on the interaction } \\
\text { between bullying and burnout }\end{array}$ \\
\hline $\begin{array}{l}\text { Karatza }^{(11)} \\
2016 \\
\text { Greece }\end{array}$ & $\begin{array}{l}\text { Investigate the relationship } \\
\text { between bullying and the } \\
\text { general health status of nursing }\end{array}$ \\
\hline $\begin{array}{l}\mathrm{Oh}^{(34)} \\
2016 \\
\text { Korea }\end{array}$ & $\begin{array}{l}\text { Identify individual and } \\
\text { institutional characteristics for } \\
\text { moral harassment }\end{array}$ \\
\hline
\end{tabular}

\begin{tabular}{|c|c|}
\hline $\begin{array}{l}\mathrm{Oh}^{(35)} \\
2016 \\
\text { Korea }\end{array}$ & $\begin{array}{l}\text { Test a model that relates } \\
\text { bullying with stress, intent } \\
\text { to quit employment and } \\
\text { adverse events. }\end{array}$ \\
\hline $\begin{array}{l}\text { Berry } \\
2016 \\
\text { USA }\end{array}$ & $\begin{array}{l}\text { Determine the differences } \\
\text { in perceived stress, state of } \\
\text { anxiety, post-traumatic stress } \\
\text { and bullying. }\end{array}$ \\
\hline
\end{tabular}

Yokoyama ${ }^{(37)} \quad$ Explore the association between

2016

Japan bullying and work environment factors

Bullying was a partial mediator of the relationship between organizational climate and burnout. Bullying affected health only when mediated by burnout.

Around $42.18 \%$ of respondents reported they had suffered intimidation/harassment in the current year. One-third (30.4\%) witnessed others being harassed and $19.6 \%$ of the incidents involved more experienced nurses.
$30.2 \%$ reported having been psychologically harassed in their workplaces in the previous six months and their general health status had worsened.

Negative affection, individualism and work in hospital specialty units predict bullying. Individualism, negative affection, type of hospital and working hours predicted verbal abuse, while the workplace was significantly associated with lateral violence.
The general mean of bullying was 1.47 , showing that the frequency was between never and not at the time. Nurses from emergency rooms were more exposed to bullying. Harassment at work has been associated with years of experience.

Bullying and stress at work and the intention to leave were associated with adverse outcomes of patients from the perspective of the interviewed nurses.

Significant differences regarding perceived stress, anxiety and post-traumatic syndrome were reported by people with frequent exposure to bullying at work.

$18.5 \%$ of the nurses reported bullying. A logistic regression analysis indicated that bullying was associated with low scores in two domains of the work environment: capacity of the nursing manager, leadership and support of nurses and adequacy of personnel and resources.

$\begin{array}{ll}\text { Blackstock } & \text { Examine the impact of } \\ 2015 & \text { organizational factors on } \\ \text { Canada } & \text { bullying and its effect on the } \\ & \text { intention to quit the job. }\end{array}$

Informal organizational alliances and improper use of organizational processes/procedures favored the increase in horizontal bullying, which, in turn, predicted the intention to quit the job.

$\begin{array}{ll}\mathrm{Ganz}^{(10)} & \text { Describe the prevalence } \\ 2015 & \text { of bullying and its } \\ \text { Israel } & \text { preventive measures. }\end{array}$

$29 \%$ reported that they were victims of bullying. Bullying levels were low to moderate. The level of prevention was weak or moderate. The higher the level of bullying, the lower the level of prevention. 


\section{First author, year and country \\ Objectives \\ Main results}

\begin{tabular}{|c|c|}
\hline $\begin{array}{l}\text { Laschinger }^{(39)} \\
2015 \\
\text { Canada }\end{array}$ & $\begin{array}{l}\text { Examine the relationship } \\
\text { between harassment and post- } \\
\text { traumatic stress disorder and } \\
\text { psychological capital. }\end{array}$ \\
\hline $\begin{array}{l}\text { Allen }^{(40)} \\
2015 \\
\text { Australia }\end{array}$ & $\begin{array}{l}\text { Examine the relationship } \\
\text { between bullying and burnout } \\
\text { and the effect of psychological } \\
\text { distancing }\end{array}$ \\
\hline $\begin{array}{l}\text { Wright(41) } \\
2015 \\
\text { USA }\end{array}$ & $\begin{array}{l}\text { Examine the relationship } \\
\text { between three types of bullying } \\
\text { with psychological/behavioral } \\
\text { responses }\end{array}$ \\
\hline
\end{tabular}

Regression analysis revealed that the most frequent exposure to harassment at work was significantly related to the symptomatology of post-traumatic stress disorder, regardless of the level of the disorder.

Bullying was associated with burnout. Psychological distancing did not significantly moderate the relationship between bullying and burnout.

Person-related bullying showed significant positive relationships with psychological/behavioral responses and medical errors. When related to work, bullying showed a significant positive relationship with psychological/behavioral responses, but not with medical errors. Feeling physically intimidated was not significant for any outcome.

\begin{tabular}{|c|c|c|}
\hline $\begin{array}{l}\text { Ekici }^{(42)} \\
2014 \\
\text { Turkey }\end{array}$ & $\begin{array}{l}\text { Evaluate bullying and its effects } \\
\text { on the performance and } \\
\text { depression of physicians and } \\
\text { nurses }\end{array}$ & $\begin{array}{l}\text { No significant differences were found between physicians } \\
\text { and nurses in terms of bullying, however, an association was } \\
\text { found between performance, depression and the violent } \\
\text { behaviors experienced. }\end{array}$ \\
\hline $\begin{array}{l}\text { Esfahani(43) } \\
2014 \\
\text { Iran }\end{array}$ & $\begin{array}{l}\text { Examine bullying in the } \\
\text { workplace among a group of } \\
\text { Iranian nurses. }\end{array}$ & $\begin{array}{l}\text { Only } 9 \% \text { of the nurses had been frequently exposed to bullying, } \\
22 \% \text { reported having been victims of bullying occasionally and } \\
69 \% \text { had never been exposed to bullying in the last year. }\end{array}$ \\
\hline $\begin{array}{l}\text { Etienne }^{(44)} \\
2014 \\
\text { Alaska }\end{array}$ & $\begin{array}{l}\text { Assess the perception of } \\
\text { nurses regarding exposure to } \\
\text { harassment }\end{array}$ & $\begin{array}{l}48 \% \text { of the nurses admitted they had been victims of bullying } \\
\text { in the previous six months. Being ignored or excluded were the } \\
\text { most common negative experiences in the workplace. }\end{array}$ \\
\hline $\begin{array}{l}\text { Ovayolu(45) } \\
2014 \\
\text { Turkey }\end{array}$ & $\begin{array}{l}\text { Determine whether nurses } \\
\text { are intimidated by other } \\
\text { team members. }\end{array}$ & $\begin{array}{l}44 \% \text { of the nurses reported experiencing one or more types of } \\
\text { bullying in the last } 12 \text { months. }\end{array}$ \\
\hline $\begin{array}{l}\text { Schlitzkus(46) } \\
2014 \\
\text { USA }\end{array}$ & $\begin{array}{l}\text { Determine whether nurses bully } \\
\text { surgery residents. }\end{array}$ & $\begin{array}{l}\text { The nurses bullied the surgery residents and } 30.2 \% \text { reported } \\
\text { intimidation in the workplace. }\end{array}$ \\
\hline $\begin{array}{l}\text { Yun } \\
2014 \\
\text { Korea }\end{array}$ & $\begin{array}{l}\text { Examine the relationship } \\
\text { between perception of the } \\
\text { work environment and moral } \\
\text { harassment }\end{array}$ & $\begin{array}{l}94.0 \% \text { reported at least one negative act in the last six months. } \\
\text { The prevalence of harassment was } 17.2 \% \text {, according to criteria } \\
\text { for assessing bullying. Significant negative correlations were } \\
\text { found between the work environment and harassment. }\end{array}$ \\
\hline $\begin{array}{l}\text { Fontes }^{(16)} \\
2013 \\
\text { Brazil }\end{array}$ & $\begin{array}{l}\text { Identify nurses who are } \\
\text { subject to bullying and } \\
\text { associated factors. }\end{array}$ & $\begin{array}{l}11.56 \% \text { were victims of bullying in the last } 12 \text { months. The } \\
\text { nurse's profile was characterized by having children, practicing } \\
\text { in public health, working at the institution for one to three years } \\
\text { and perceiving oneself as bullied. }\end{array}$ \\
\hline $\begin{array}{l}\text { Vogelpohl(48) } \\
2013 \\
\text { USA }\end{array}$ & $\begin{array}{l}\text { Investigate bullying among } \\
\text { new graduates. }\end{array}$ & $\begin{array}{l}\text { Nurses, physicians or relatives of patients were the main sources } \\
\text { of bullying, and } 29.5 \% \text { of the nurses considered leaving the } \\
\text { nursing profession. }\end{array}$ \\
\hline
\end{tabular}




\section{First author, year and country

$\begin{array}{ll}\text { Berry }^{(49)} & \text { Determine the prevalence and } \\ 2012 & \text { effects of moral harassment in } \\ \text { USA } & \text { the work of new graduates. }\end{array}$

Gaffney ${ }^{(50)}$

2012

USA
44.7\% reported bullying and 55.3\% reporting no bullying. The individuals who bullied were primarily more experienced nursing coworkers (63\%). The productivity of the nurse was negatively affected

\begin{tabular}{|c|c|c|}
\hline $\begin{array}{l}\text { Gaffney } \\
2012 \\
\text { USA }\end{array}$ & $\begin{array}{l}\text { Report the experiences } \\
\text { of nurses regarding } \\
\text { workplace harassment. }\end{array}$ & $\begin{array}{l}\text { When nurses were confronted with harassment in the } \\
\text { workplace, they became involved in a process of doing things } \\
\text { right, they put bullying in context and they evaluated the } \\
\text { situation, acted and judged the results of their actions. }\end{array}$ \\
\hline $\begin{array}{l}\text { Farrel }^{(51)} \\
2012 \\
\text { Australia }\end{array}$ & $\begin{array}{l}\text { Report the nature and extent of } \\
\text { aggression and bullying. }\end{array}$ & $\begin{array}{l}52 \% \text { reported some form of aggression. } 36 \% \text { suffered violence } \\
\text { mainly from patients or their visitors/relatives and } 32 \% \text { from } \\
\text { coworkers or their managers/supervisors. }\end{array}$ \\
\hline $\begin{array}{l}\text { Laschinger }^{(52)} \\
2012 \\
\text { Canada }\end{array}$ & $\begin{array}{l}\text { Test a model that relates } \\
\text { leadership to the experiences of } \\
\text { new graduates regarding moral } \\
\text { harassment }\end{array}$ & $\begin{array}{l}\text { Authentic leadership had a negative direct effect on workplace } \\
\text { harassment that had a direct positive effect on emotional } \\
\text { exhaustion. Authentic leadership, moral harassment and } \\
\text { emotional exhaustion had significant direct effects on job } \\
\text { satisfaction and a lesser desire to quit work. }\end{array}$ \\
\hline $\begin{array}{l}\text { Hutchinson }^{(17)} \\
2010 \\
\text { Australia }\end{array}$ & $\begin{array}{l}\text { Test a multidimensional model } \\
\text { of workplace bullying. }\end{array}$ & $\begin{array}{l}\text { The study emphasizes a strong relationship between } \\
\text { organizational characteristics, bullying and the resulting } \\
\text { consequences. An incremental relationship was found between } \\
\text { the latent factors in the model and indicate the direction of the } \\
\text { relationship between the three organizational factors, bullying } \\
\text { and the resulting consequences. }\end{array}$ \\
\hline
\end{tabular}

Chart 1 - Characterization of the studies in relation to the first author, year of publication, country, objectives and main results Source: Research data, 2018.

\section{DISCUSSION}

The evaluation of studies addressing bullying in the nursing environment made it possible to systemize some results. It should be noted that most of the studies were published in Asia (39.5\%), followed by North America (31.5\%). Few publications on the subject were found for South America and Africa, indicating the need for further studies in these localities ${ }^{(16,28)}$.

Regarding the year of publication, $97.3 \%$ of the studies were published from 2014, demonstrating a growing interest of researchers on the subject of bullying in nursing practice environment.

Most articles sought to identify the existence of bullying among nursing professionals using specific data collection instruments in the fields of psychology and health care. In this review, we observed a predominance of the
Negative Acts Questionnaire Revised (NAQ-R), used in 21 studies $(2,10,11,14,22-26,28,33-37,39,41,44,46-49,52)$. The original version of this instrument contains 22 items that report negative acts in the work environment and it is widely used in research on bullying ${ }^{(53)}$.

The analysis of the objectives of the studies that addressed bullying in nursing allowed us to identify three approaches to this behavior, namely: the perception of the teams regarding the presence of this behavior in the workplace, the influence of bullying on the physical health and professional performance of the victims and the construction of theoretical models to formulate postulates that relate bullying to the determinant factors of this act of violence at work. These approaches are presented in three categories: 1) perception of bullying by professionals, 2) impact of bullying on health and professional performance and 3) construction of theoretical models on bullying behavior in nursing. 


\section{Category 1. Perception of bullying by professionals}

In the evaluation of the perception of bullying, the studies presented and applied different instruments to identify the indices of this behavior, which were perceived by the nursing professionals. The percentage of bullying among nursing professionals ranged from $9 \%$ to $94 \%\left({ }^{(43-49)}\right.$, and some studies related characteristics of the professional $^{(14,29,31,49)}$ and the environment ${ }^{(21,24,26,33,52)}$ as factors associated with bullying. It is noteworthy that the lowest percentage of bullying identified in this review corresponds to research based solely on the self-reports of nurses from a province of Azerbaijan, a region marked by strong cultural peculiarities ${ }^{(43)}$.

The differences between the prevalence found in studies on bullying may reflect the reality of the working conditions of many nursing professionals, considering particular aspects of their region and culture, although it is possible to find variations due to difficulties in establishing standardized definitions on bullying and appropriate data collection methodologies for bullying in health institutions ${ }^{(54)}$.

Regarding the characteristics of the workers who influence the perception of bullying, the variable age was related to bullying in a study conducted in southern Taiwan (29), in which older nurses, with more professional experience, showed negative behavior in relation to younger nurses and often questioned their skills and ability to resolve conflicts ${ }^{(14)}$. Furthermore, the variable years of experience influenced the behavior of bullying since newly graduated workers were more exposed to violent behavior at work ${ }^{(49)}$, exemplified by a study in which $19.5 \%$ of the acts of bullying were practiced by more experienced nurses ${ }^{(31)}$. These findings indicate that some nurses use their professional experience as a form of power, while it is expected that the knowledge acquired in the nursing practice environment be passed on to the novice professionals.

In relation to the work environment, studies pointed out that the organizational climate ${ }^{(24,33)}$ of the institutions and hierarchy-oriented work structures ${ }^{(21,26)}$ - to the detriment of personal work-based relationships - were related to acts of bullying. The absence of leadership figures ${ }^{(52)}$ was also related to the higher probability of acts of violence in the workplace.

\section{Category 2. Impact of bullying on health and professional performance}

Bullying mostly affects the overall health status of workers $^{(14,29,39)}$. The victims of bullying exhibited several physical and emotional manifestations, mainly symptoms of stress, anxiety and depression ${ }^{(21,36,37,40)}$ and a strong relationship with cases of burnout ${ }^{(40)}$ was observed in environments where negative acts against workers were reported. These manifestations reveal the high degree of psychological impairment nursing professionals experience in relation to bullying and work.

With regard to nursing, studies show that the effects of this type of violence on workers go beyond the physical and emotional manifestations, often demonstrated by high levels of stress, anxiety and depression ${ }^{(29)}$. Professional development is also affected by bullying, which can be perceived by an increase in absenteeism that reduces productivity and efficiency and causes social isolation, dissatisfaction with work and coworkers, often resulting in job abandonment ${ }^{(21-22,24,28,38,52)}$.

Therefore, it is important to perceive and address the nursing workplace in order to create standards of quality of life and professional performance. The low level of work satisfaction, especially in health care, causes other negative outcomes related to bullying, such as job abandonment ${ }^{(20)}$ and even abandonment of the profession ${ }^{(14)}$ since workers believe they are not capable of continuing their activities or of adequately performing their duties.

\section{Category 3. Construction of theoretical models on bullying behavior in nursing}

In this category, studies on bullying in nursing sought to construct theoretical models $s^{(17,21,33,35)}$ to identify patterns of bullying behavior according to several factors that could sustain these acts of violence in the nursing environment. The variables organizational culture ${ }^{(17,33)}$, burnout ${ }^{(33)}$ and intention to quit the job ${ }^{(21,35)}$ were related to bullying in the models proposed in this review.

The identification of a category related to bullying in nursing that proposes the construction of theoretical models on the subject shows that researchers still need to identify essential assumptions and characteristics for bullying that can relate several aspects of nursing to the occurrence of bullying in health institutions.

By knowing the variables that determine this behavior in the nursing work environment, it is possible to support the implementation of actions that prevent bullying among nursing professionals and occupational programs that favor a positive perception of the nursing practice in health care. 


\section{aCONCLUSIONS}

The findings of this review indicate that studies on bullying in the nursing work environment sought to identify the profile of this behavior in health institutions and highlight the repercussions of these acts on workers and the institution.

Nursing professionals exposed to bullying may develop negative manifestations in their overall health and feel dissatisfied with their work, peers and superiors, culminating in weak social relations at work and the desire to quit their jobs.

The characteristics of bullying behavior found in the publications of this study justify the need to map social relationships among nursing workers by highlighting the main indicators of bullying. Consequently, the early identification of such behavior in the work environment can help service managers develop programs to prevent and control this behavior in health institutions.

The limitation identified in this review is the absence of studies addressing effective strategies to prevent bullying or proposals for institutional policies that have presented important results in identifying and controlling this behavior in the nursing practice environment.

\section{Q REFERENCES}

1. Andrade CB, Assis SG. Assédio moral no trabalho, gênero, raça e poder: revisão de literatura. Rev Bras Saúde Ocup. 2018;43:e11. doi: https://doi. org/10.1590/2317-6369000012917

2. Borges EMN, Ferreira TJR. Bullying no trabalho: adaptação do Negative Acts Questionnaire-Revised (NAQ-R) em enfermeiros. Rev Port Enferm Saúde Mental. 2015 [cited 2019 Jan 10];(13):25-33. Available from: http://www.scielo.mec. pt/scielo.php?script=sci_arttext\&pid=\$1647-21602015000200004\&lng =pt \&nrm $=i \& t \operatorname{lng}=p t$

3. Cheung T, Lee PH, Yip PSF. Workplace violence toward physicians and nurses: prevalence and correlates in Macau. Int J Environ Res Public Health. 2017;14(8): 879. doi: https://doi.org/10.3390/ijerph14080879

4. Park M, Cho, SH, Hong, HJ. Prevalence and perpetrators of workplace violence by nursing unit and the relationship between violence and the perceived work environment. J Nurs Scholarsh. 2015;47(1):87-95. doi: https://doi. org/10.1111/jnu. 12112

5. Silva IV, Aquino EML, Pinto ICM. Características psicométricas do Negative Acts Questionnaire para detecção do assédio moral no trabalho: estudo avaliativo do instrumento com uma amostra de servidores estaduais da saúde. Rev Bras Saúde Ocup. 2017;42:e2. doi: https://doi.org/10.1590/2317-6369000128715

6. Guimarães LAM, Rimoli A0. "Mobbing" (assédio psicológico) no trabalho: uma síndrome psicossocial multidimensional. Psicol: Teor Pesqui. 2006;22(2):18391. doi: https://doi.org/10.1590/50102-37722006000200008

7. Bobroff MCC, Martins JT. Assédio moral, ética e sofrimento no trabalho. Rev Bioética 2013;21(2):251-8. doi: https://doi.org/10.1590/S198380422013000200008
8. Einarsen S, Raknes BRL, Matthiesen SB. Bullying and harassment at work and their relationships to work environment quality: an exploratory study. Eur Work Organiz Psychol. 1994;4(4):381-401. doi: https://doi. org/10.1080/13594329408410497

9. Sauer PA, McCoy TP. Nurse Bullying: Impact on nurses' health. West J Nurs Res. 2017;39(12):1533-46. doi: https://doi.org/10.1177/0193945916681278

10. Ganz FD, Levy H, Khalaila R, Arad D, Bennaroch K, Kolpak 0, et al. Bullying and its prevention among intensive care nurses. J Nurs Scholarsh. 2015;47(6):505-11. doi: https://doi.org/10.1111/jnu.12167

11. Karatza C, Zyga S, Tziaferi S, Prezerakos P. Workplace bullying and general health status among the nursing staff of Greek public hospitals. Ann Gen Psychiatry. 2016;15:7. doi: https://doi.org/10.1186/s12991-016-0097-z

12. Norton P, Costa V, Teixeira J, Azevedo A, Roma-Torres A, Amaro J, et al. Prevalence and determinants of bullying among health care workers in Portugal. Workplace Health Saf. 2017;65(5):188-96. doi: https://doi. org/10.1177/2165079916666545

13. Charilaos K, Michael G, Chryssa BT, Panagiota D, George CP, Christina D. Validation of the Negative Acts Questionnaire (NAQ) in a sample of Greek teachers. Psychology 2015;6(1):63-74. doi: https://doi.org/10.4236/psych.2015.61007

14. Karatza C, Zyga S, Tziaferi S, Prezerakos P. Workplace bullying among the nursing staff of Greek public hospitals. Workplace Health Saf. 2017;65(2):57-64. doi: https://doi.org/10.1177/2165079916657106

15. Bordignon M, Monteiro Ml. Violence in the workplace in nursing: consequences overview. Rev Bras Enferm. 2016;69(5):939-42. doi: https://doi. org/10.1590/0034-7167-2015-0133

16. Fontes KB, Santana RG, Pelloso SM, Carvalho MDB. Fatores associados ao assédio moral no ambiente laboral do enfermeiro. Rev Latino-Am Enfermagem. 2013;21(3):758-64. doi: https://doi.org/10.1590/S0104-11692013000300015

17. Hutchinson M, Wilkes $L$, Jackson D, Vickers MH. Integrating individual, work group and organizational factors: testing a multidimensional model of bullying in the nursing workplace. J Nurs Manag. 2010;18(2):173-81. doi: https://doi. org/10.1111/j.1365-2834.2009.01035.x

18. Whittemore R, Knafl K. The integrative review: updated methodology. J Adv Nurs. 2005;52(5):546-53. https://doi.org/10.1111/j.1365-2648.2005.03621.x

19. Moher D, Liberati A, Tetzlaff J, Altman DG. The PRISMA Group. Preferred reporting items for systematic reviews and meta-analyses: the PRISMA Statement. PLoS Med. 2009;21;6(7):e1000097. doi: https://doi.org/10.1371/ journal.pmed. 1000097

20. Logan TR, Michael Malone D. Nurses' perceptions of teamwork and workplace bullying. I Nurs Manag. 2018;26(4):411-9. doi: https://doi.org/10.1111/ jonm. 12554

21. Yun S, Kang J. Influencing factors and consequences of workplace bullying among nurses: a structural equation modeling. Asian Nurs Res. 2018;12(1):2633. doi: https://doi.org/10.1016/j.anr.2018.01.004

22. Savaşan A, Özgür $G$. The relationship between personality characteristics and workplace bullying of nurses. J Psychiatric Nurs. 2018; 9(1):29-35. doi: https:// doi.org/10.14744/phd.2017.66487

23. Olender $L$. The relationship between and factors influencing staff nurses' perceptions of nurse manager caring and exposure to workplace bullying in multiple healthcare settings. J Nurs Adm. 2017;47(10):501-7. doi: https://doi. org/10.1097/NNA.00000000000000522

24. Olsen $E$, Bjaalid $G$, Mikkelsen A. Work climate and the mediating role of workplace bullying related to job performance, job satisfaction, and work 
ability: a study among hospital nurses. J Adv Nurs. 2017;73(11):2709-19. doi: https://doi.org/10.1111/jan.13337

25. Kang J, Kim JI, Yun S. Effects of a cognitive rehearsal program on interpersonal relationships, workplace bullying, symptom experience, and turnover intention among nurses: a randomized controlled trial. J Korean Acad Nurs. 2017;47(5):689-99. doi: https://doi.org/10.4040/jkan.2017.47.5.689

26. An Y, Kang J. Relationship between organizational culture and workplace bullying among Korean nurses. Asian Nurs Res. 2016;10(3):234-9. doi: https:// doi.org/10.1016/j.anr.2016.06.004

27. Blackwood K, Bentley T, Catley B, Edwards M. Managing workplace bullying experiences in nursing: the impact of the work environment. Public Money Manage. 2017;37(5):349-56. doi: https://doi.org/10.1080/09540962.2017.1328205

28. Nwaneri AC, Onoka AC, Onoka CA. Workplace bullying among nurses working in tertiary hospitals in Enugu, southeast Nigeria: implications for health workers and job performance. J Nurs Educ Pract. 2017;7(2):69-78. doi: https://doi. org/10.5430/jnep.v7n2p69

29. Ma SC. Hospital nurses' attitudes, negative perceptions and negative acts regarding work-place bullying. Ann Gen Psychiatry. 2017;16:33. doi: https:// doi.org/10.1186/s12991-017-0156-0

30. Bardakçı E, Günüşen NP. Influence of workplace bullying on Turkish nurses' psychological distress and nurses' reactions to bullying. J Transcul Nurs. 2016;27(2):166-71. doi: https://doi.org/10.1177/1043659614549073

31. Tee S, ÜzarYO, Russell MW. Workplace violence experienced by nursing students: a UK survey. Nurse Educ Today. 2016;41:30-5. doi: https://doi.org/10.1016/j. nedt.2016.03.014

32. Fang L, Huang SH, Fang SH. Workplace bullying among nurses in South Taiwan. J Clin Nurs. 2016;25(17-18):2450-6. doi: https://doi.org/10.1111/jocn. 13260

33. Giorgi G, Mancuso S, Perez FF, D’Antonio AC, Mucci N, Cupelli V, et al. Bullying among nurses and its relationship with burnout and organizational climate. Int J Nurs Pract. 2016;22(2):160-8. doi: https://doi.org/10.1111/ijn.12376

34. Oh H, Uhm DC, Yoon YJ. Factors affecting workplace bullying and lateral violence among clinical nurses in Korea: descriptive study. J Nurs Manag. 2016;24(3):327-35. doi: https://doi.org/10.1111/jonm.12324

35. Oh H, Uhm D, Yoon Y. Workplace bullying, job stress, intent to leave, and nurses' perceptions of patient safety in South Korean hospitals. J Nurs Res. 2016;65(5):380-8. doi: https://doi.org/10.1097/NNR.0000000000000175

36. Berry PA, Gillespie GL, Fisher BS, Gormley D, Haynes JT. Psychological distress and workplace bullying among registered nurses. Online J Issues Nurs. 2016 [cited 2019 Jan 20];21(3). Available from: http://0jin.nursingworld.org/ MainMenuCategories/ANAMarketplace/ANAPeriodicals/0JIN/TableofContents/ Vol-21-2016/No3-Sept-2016/Articles-Previous-Topics/Psychological-Distressand-Workplace-Bullying.html

37. Yokoyama M, Suzuki M, Takai Y, Igarashi A, Noguchi-Watanabe M, YamamotoMitani N. Workplace bullying among nurses and their related factors in Japan: a cross-sectional survey. J Clin Nurs. 2016;25(17-18):2478-88. doi: https://doi. org/10.1111/jocn. 13270

38. Blackstock S, Harlos K, Macleod MLP, Hardy CL. The impact of organisational factors on horizontal bullying and turnover intentions in the nursing workplace. J Nurs Manag. 2015;23(8):1106-14. doi: https://doi.org/10.1111/jonm.12260
39. Laschinger HKS, Nosko A. Exposure to workplace bullying and post-traumatic stress disorder symptomology: the role of protective psychological resources. J Nurs Manag. 2015;23(2):252-62. doi: https://doi.org/10.1111/jonm. 12122

40. Allen BC, Holland P, Bus B, Reynolds R. The effect of bullying on burnout in nurses: the moderating role of psychological detachment. J Adv Nurs. 2015;71(2):38190. doi: https://doi.org/10.1111/jan.12489

41. Wright W, Khatri N. Bullying among nursing staff: relationship with psychological/behavioral responses of nurses and medical errors. Health Care Manage Rev. 2015;40(2):139-47. doi: https://doi.org/10.1097/ HMR.0000000000000015

42. Ekici D, Beder A. The effects of workplace bullying on physicians and nurses. Aust J Adv Nurs. 2014 [cited 2019 Jan 12];31(4):24-33. Available from: http://www. ajan.com.au/Vol31/lssue4/31-4.pdf

43. Esfahani AN, Shahbazi G. Workplace bullying in nursing: the case of Azerbaijan province, Iran. Iran J Nurs Midwifery Res. 2014 [cited 2019 Jan 20];19(4):409-15. Available from: https://www.ncbi.nlm.nih.gov/pmc/articles/PMC4145498/

44. Etienne, E. Exploring workplace bullying in nursing. Workplace Health Saf. 2014;62(1):6-11. doi: https://doi.org/10.1177/216507991406200102

45. Ovayolu 0, Ovayolu N, Karadag G. Workplace bullying in nursing. Workplace Health Saf. 2014;62(9):370-4. https://doi.org/10.3928/21650799-20140804-04

46. Schlitzkus LL, Vogt KN, Sullivan ME, Schenarts KD. Workplace bullying of general surgery residents by nurses. J Surg Educ. 2014;71(6):e149-54. doi: https://doi. org/10.1016/j.jsurg.2014.08.003

47. Yun S, Kang J, Lee Y0, Yi Y. Work environment and workplace bullying among Korean intensive care unit nurses. Asian Nurs Res. 2014;8(3):219-25. doi: https://doi.org/10.1016/j.anr.2014.07.002

48. Vogelpohl DA, Rice SK, Edwards ME, Bork CE. New graduate nurses' perception of the workplace: have they experienced bullying? J Prof Nurs. 2013;29(6):41422. doi: https://doi.org/10.1016/j.profnurs.2012.10.008

49. Berry PA, Gillespie GL, Gates D, Schafer J. Novice nurse productivity following workplace bullying. J Nurs Scholarsh. 2012;44(1):80-7. doi: https://doi. org/10.1111/j.1547-5069.2011.01436.x

50. Gaffney DA, DeMarco RF, Hofmeyer A, Vessey JA, Budin WC. "Making things right: nurses' experiences with workplace bullying - a grounded Theory." Nurs Res Pract. 2012;2012:243210. doi: https://doi.org/10.1155/2012/243210

51. Farrel GA, Shafiei T. Workplace aggression, including bullying in nursing and midwifery: a descriptive survey (the SWAB study). Int J Nurs Stud. 2012;49(11):1423-31. doi: https://doi.org/10.1016/j.jinurstu.2012.06.007

52. Laschinger HKS, Wong CA, Grau AL. The influence of authentic leadership on newly graduated nurses' experiences of workplace bullying, burnout and retention outcomes: a cross-sectional study. Int J Nurs Stud. 2012;49(10):126676. doi: https://doi.org/10.1016/j.jinurstu.2012.05.012

53. Notelaers G, Einarsen S, De Witte H, Vermunt JK. Estimating the prevalence of bullying at work: a latent class cluster approach. Work Stress. 2006;20(4):289302. doi: https://doi.org/10.1080/02678370601071594

54. Zachariadou T, Zannetos, S, Chira SE, Gregoriou S, Pavlakis A. Prevalence and forms of workplace bullying among health-care professionals in Cyprus: Greek version of "Leymann Inventory of Psychological Terror" Instrument. Saf Health Work. 2017;9(3):339-46. doi: https://doi.org/10.1016/j.shaw.2017.11.003

\section{Corresponding author:}

Roberta Nazario Aoki: 